\title{
The Opium Wars, Opium Legalization and Opium Consumption in China
}

\section{Citation}

Feige, Chris, and Jeffrey A. Miron. 2008. The opium wars, opium legalization and opium consumption in China. Applied Economics Letters 15(12): 911-913.

\section{Published Version}

doi:10.1080/13504850600972295

\section{Permanent link}

http://nrs.harvard.edu/urn-3:HUL.InstRepos:11379703

\section{Terms of Use}

This article was downloaded from Harvard University's DASH repository, and is made available under the terms and conditions applicable to Other Posted Material, as set forth at http:// nrs.harvard.edu/urn-3:HUL.InstRepos:dash.current.terms-of-use\#LAA

\section{Share Your Story}

The Harvard community has made this article openly available.

Please share how this access benefits you. Submit a story.

\section{Accessibility}


NBER WORKING PAPER SERIES

\title{
THE OPIUM WARS, OPIUM LEGALIZATION, AND OPIUM CONSUMPTION IN CHINA
}

\author{
Jeffrey A. Miron \\ Chris Feige \\ Working Paper 11355 \\ http://www.nber.org/papers/w11355

\section{NATIONAL BUREAU OF ECONOMIC RESEARCH} \\ 1050 Massachusetts Avenue \\ Cambridge, MA 02138 \\ May 2005
}

We are grateful to Pat Giersch and Richard Grossman for comments on an earlier draft. We thank Ed Glaeser and Mark Ramseyer for spurring our interest in this topic. The views expressed herein are those of the author(s) and do not necessarily reflect the views of the National Bureau of Economic Research.

(O2005 by Jeffrey A. Miron and Chris Feige. All rights reserved. Short sections of text, not to exceed two paragraphs, may be quoted without explicit permission provided that full credit, including $\odot$ notice, is given to the source. 
The Opium Wars, Opium Legalization, and Opium Consumption in China Jeffrey A. Miron and Chris Feige

NBER Working Paper No. 11355

May 2005

JEL No. K4, N4

\title{
ABSTRACT
}

The effect of drug prohibition on drug consumption is a critical issue in debates over drug policy. One episode that provides information on the consumption-reducing effect of drug prohibition is the Chinese legalization of opium in 1858. In this paper we examine the impact of China's opium legalization on the quantity and price of British opium exports from India to China during the 19th century. We find little evidence that legalization increased exports or decreased price. Thus, the evidence suggests China's opium prohibition had a minimal impact on opium consumption.

\author{
Jeffrey A. Miron \\ Department of Economics \\ Harvard University \\ Cambridge, MA 02183 \\ and NBER \\ miron@fas.harvard.edu \\ Chris Feige \\ State Street Bank \\ cfeige@wesleyan.edu
}




\section{Introduction}

The effect of drug prohibition on drug consumption is a critical issue in debates over drug policy. Prohibition advocates claim drug use would mushroom if drugs were legal, while prohibition critics believe use would increase modestly, if at all. Evidence on this issue is scarce due mainly to the lack of data on prohibited commodities.

One episode that provides information on the consumption-reducing effect of drug prohibition is the Chinese legalization of opium in 1858. India was a major opium producer opium during the $19^{\text {th }}$ century, and the British East India Company exported much of this opium to China and other parts of Southeast Asia. China prohibited the consumption and importation of opium during the early part of the century, but after the Second Opium War China yielded to British pressure and legalized opium.

The critical feature of this episode is that the British East India Company kept records of the quantity and price of opium exports from India to China. The exports from India were legal throughout the 1800 s even though importation into China, and consumption within China, were prohibited until 1858. Exportation occurred before this date because third party entrepreneurs purchased the opium in India and smuggled it into China. If China's opium prohibition reduced consumption to a substantial degree, legalization should have increased exports from India to China, unless legalization also spurred production within China. In that case, however, Chinese substitution of domestic for imported opium should have reduced the export price of Indian opium. Thus, the joint behavior of opium exports and price can indicate whether prohibition reduced opium consumption.

In this paper we examine the impact of China's legalization of opium on the quantity and price of British opium exports from India to China during the $19^{\text {th }}$ century. We find little evidence that legalization increased exports or decreased price. Thus, the evidence suggests China's opium prohibition had a minimal impact on opium consumption. 
The remainder of the paper proceeds as follows. Section II provides background on the history of opium in China and on the British participation in the opium trade. Section III examines the impact of legalization on opium exports and price. Section IV concludes.

\section{Background on Opium and the History of Opium in China}

Opium is produced from the opium poppy, an annual flowering plant native to Turkey and first domesticated in the Mediterranean region during the Roman Empire. The plant's seedpod contains a latex solution that exudes if the pod is scored with a razor or other sharp instrument. This latex is known as raw opium, and it contains morphine, codeine, noscapine and other alkaloids with analgesic properties. Raw opium can be eaten or diluted in liquid, but consumption in this form is unusual. The standard approach is to boil raw opium and then dry it for smoking. ${ }^{1}$

The opium poppy was introduced into China between the $4^{\text {th }}$ and $7^{\text {th }}$ centuries by Arab traders, and it was cultivated widely for centuries before the East India Company began trading in Asia. An $11^{\text {th }}$ century Chinese medical doctor referred to opium as medicine, and it was used to cure diarrhea, induce sleep, and reduce the pain of diseases such as dysentery and cholera. ${ }^{2}$

The English arrived in China in 1637 and were allowed to open a trading station in Canton in 1715 (Beeching 1975, p.11). During this time many Western powers imported both opium and tobacco into China. In 1729, rising opium use prompted an imperial edict from Yung Ching that forbade the sale of opium for smoking purposes. In 1799, an imperial edict also prohibited importation of opium for smoking purposes. Opium's sale and use were "classed with robbery and instigation to murder, and punished with banishment or death." Importation was

\footnotetext{
${ }^{1}$ For a more detailed account of the opium production process, see Booth (1996, Chapter 1).

${ }^{2}$ See http://www.druglibrary.org/schaffer/heroin/opiwar1.htm.
} 
treated just as harshly, as "the opium on seizure is burnt, the vessel confiscated and the Chinese possessing it are liable to death" (Rowntree 1905, pp.6-13).

The East India Company obtained an opium monopoly in Bengal in 1773, and in 1830 the Company added Bombay opium to its sphere of control. From the 1770s it began heavier trade in Canton. While official Chinese policy barred the opium trade in 1799, merchants welcomed the financial rewards. Often the English traded opium for tea at Canton.

Leading up to the 1799 edict, the Chinese became more wary of the opium trade and the ever-expanding British influence in their country. Under pressure from the Chinese government, which threatened to stop the profitable tea trade, the East India Company stopped exporting opium directly to China in 1796 and began selling in Calcutta to private English merchants. These merchants delivered the opium to China, but the Company denied responsibility for the smuggling and thus retained other trading rights. In both 1814 and 1831, the Emperor decreed even stricter laws against importation and sale of opium (Chang 1964, p.220).

By the 1830's the Chinese economy was in recession and the balance of trade had turned against China. The opium trade was blamed for the drainage of silver from the country and for the economic slowdown. There was no reason to believe the opium trade was the main reason for the silver famine or the recession, but a corrupt army and weakened bureaucracy, combined with the slowed economy, made opium an easy scapegoat for the dynasty's problems (Polachek 1992, p.104).

In 1836 the Emperor held a series of "Opium Debates" between those favoring legalization and those favoring further suppression of opium. Legalizers claimed the real issues with opium were organized crime and the silver drain that was ruining the economy. They argued that legalizing opium and taxing it would generate huge revenues, and they believed that enforcing opium prohibition would be expensive and strengthen the already feared lower bureaucracy in China. The moralists claimed that disregard for the law was no reason to repeal it and that legalization would result in everyone smoking. They believed opium was evil and felt it 
was the emperor's duty to save the people from this evil. The legalizers appeared close to victory until a rival political faction thwarted the initiative (Polachek 1992, p.114).

After the Opium Debates, opium addiction became a capital offense and eliminating the internal trade became a major focus of the Ching dynasty. Opium prohibition was "a law condemning opium smokers to strangulation, and opium dealers to decapitation." (Rowntree 1905, p.65). The crackdown on internal trade did not appear to reduce use, however, so the Emperor turned his attention to the foreigners who were bringing the opium to China.

The Chinese tried to keep foreigners at arms length and scoffed at assertions of British superiority (Beeching 1975, p.50). Smugglers became more aggressive, and scuffles with Chinese authorities only emboldened them. The authorities were unable to bring smugglers to justice, as Chinese officials "steadily accepted bribes and acted as willing accomplices" (Rowntree, p.27). In 1839, the Chinese made a last effort at closing off their country to foreigners (Polachek 1992, p.103).

Opium was a major point of foreign contact, so in 1839 the emperor assigned Lin TsehSen to the post of imperial commissioner with the task of ridding China of the opium problem. Commissioner Lin was already anti-opium, and he immediately used force against the British in Canton, seizing their opium and destroying it without compensation. The British were outraged but did not cease the trade, fighting their way up the river to trading ports and bringing more opium to Canton. The Chinese responded by stopping shipments of food to the British ships and poisoning their water supplies. Drunken British sailors killed a Chinese villager, and Captain Elliot, who was seen as the British civil authority in the area, refused to allow the sailors to be tried under Chinese law.

Commissioner Lin responded by sending Chinese junkships, which attacked British ships but did little harm. China continued to assert its superiority and sent letters to London warning the British of their downfall if they disobeyed China. The British responded by sending more warships to Canton and destroying Lin's army. Commissioner Lin lied to the emperor, claiming 
stunning defeats of the barbaric British and giving short timetables for the end of the opium trade. Eventually the British captured strategic points on the coast and fortified and blockaded Canton, forcing Chinese surrender. Lin was banished and the Treaty of Nanjing was signed in $1842 .^{3}$

The treaty gave Hong Kong to the British and opened new ports to British trade. It forbade the Chinese from trying British sailors under Chinese law (extraterritoriality) and gave Britain "most-favored-nation status" in trade. Opium was not a major focus of the treaty, and the British negotiators were simply instructed to "impress upon the Chinese... how much it would be for the interest of that Government to legalize the trade." In particular, the British urged the Chinese to legalize and tax opium to alleviate their financial woes and gain control over the trade. The emperor disagreed, saying "nothing will induce me to derive a revenue from the vice and misery of my people" (Rowntree 1905, p.71).

The second Opium War broke out in 1856, when Canton officials boarded the Arrow, a vessel accused of piracy, and ripped down a British flag. British ships attacked the city in response (Beeching 1975, p. 214).

The British again won the war easily. The Treaty of Tientsin, signed in June of 1858 , contained no reference to the opium trade but further opened legal trade in favor of the British. ${ }^{4}$ Lord Elgin, the British negotiator, saw opium as a deplorable evil rather than a term of negotiation. He nevertheless believed it "had" to be legalized, yet he "could not bring himself to tell the Chinese that the time had come to legalize this lucrative, but demoralizing traffic" (Rowntree 1905, p. 87). After the peace, the British again supported legalization as the only way to control the trade. China finally succumbed, stating, "China still retains her objection to the use of the drug on moral grounds, but the present generation of smokers, at all events, must and will

\footnotetext{
${ }^{3}$ For further details, see Chang (1964, pp. 189-213) and Waley (1995).

${ }^{4}$ Although the Treaty was signed in 1858, hostilities did not conclude until 1860.
} 
have opium" (Rowntree 1905, p.88). The Chinese legalized opium in 1858, with a tariff of about $8 \%$.

\section{Legalization's Impact on Opium Exports and Price}

We now examine whether China's legalization of opium led to a substantial increase in Chinese opium consumption. Since data on Chinese opium consumption are not available, we use data on the quantity and price of opium exports from India to China. The exportation of opium from India was legal throughout the $19^{\text {th }}$ century, so these data should indicate the amounts leaving India. Assuming there was no substantial change in other sources of opium, the export data indicate the trends in Chinese opium consumption. ${ }^{5}$ If there was a substantial increase in Chinese opium production, or in opium imported from a third country, exports from India to China would not indicate the behavior domestic consumption. In this case, however, the shift in demand from Indian to Chinese opium should have depressed the export price of Indian opium. Thus, examination of the quantity and price of opium exports can determine the impact of legalization on Chinese opium consumption. ${ }^{6}$

Data

The data sources for exports are Greenberg's (1951) British Trade and the Opening of China 1800-1842 for the period 1801-1839 and Financial and Commercial Statistics of British India (1903) for the period 1840-1902. ${ }^{7}$ Greenberg's data are a compilation of contemporary

\footnotetext{
5 In fact, China initially legalized importation and consumption but not domestic production; in the early 1870s, China legalized domestic production as well (Rowntree 1905, pp.96-98). Thus, there would not necessarily have been substantial substitution during the early legalization years in any case.

${ }^{6}$ The amount of opium imported into China from elsewhere rarely exceeded $5 \%$ and only got above $10 \%$ in the late 1870's and early 1880's. Relatedly, the correlation between Indian exports and Chinese imports was 0.68 for the period 1863-1899. (International Anti-Opium Association 1922, p.16).

${ }^{7}$ The two sources overlap for the years 1830-1839 and are similar for this period.
} 
lists, which were organized in Morse's International Relations, Vol. 1. The Financial and Commercial Statistics series are the recordings of the British East India Company's sales at their scales for export to India. The opium was sold to merchants to be loaded onto boats headed for China. While it is possible some was rerouted by merchants, it is unlikely they lied as no higher tariff was charged for opium going to China as compared to any other export destination. The series on total exports is the sum of two series, exports from Bengal and exports from Bombay.

The data sources for export prices are Rowntree (1905, Appendix II, p.285) for the period 1801-1829 and Financial and Commercial Statistics for the period 1831-1902. The data are the prices at which the East India Company sold opium at the scales in India to individual merchants for shipment to China and elsewhere.

Results

Figure 2 presents data on exports of opium from India to China for the period 1801-1902. The data are measured in number of chests per Chinese population. Overall there is a strong upward trend, beginning around 1820. This trend potentially reflects increasing population, higher income, or an expanding taste for opium. There is substantial volatility during certain periods, especially the war years (1839-1842 and 1855-1866).

The key feature of the data is the absence of increased export growth after legalization. If anything, the trend line becomes less steep around the time of legalization, and it eventually turns downward. If legalization increased consumption, exports should have grown faster after legalization, barring a substantial substitution toward domestically produced opium. Thus, the raw data fail to indicate that legalization increased consumption.

Table 1 examines this issue more carefully by presenting regressions of exports per Chinese population on a dummy for legalization, a dummy for the war periods, the price of rice, 
population, trend and trend squared. ${ }^{8} \quad$ The legalization dummy equals 0 through 1857 and 1 thereafter. The war dummy equals 1 in the years $1839-1842$ and 1855-1866, and 0 otherwise. Both wars ended before the dates used, but upheaval that affected the opium trade continued until after the official ending dates. We include the price of rice as a proxy for the (inverse of) income. We include population as a further control for income or the taste for opium. All regressions report Newey and West (1986) $t$-statistics.

The results indicate that, after controlling for pre-existing trends, there is little effect of legalization on opium exports. The results in column (1) indicate that exports from India to China were higher post-legalization. The results in column (2), which control for war periods, the price of rice, and population, are similar. The results in columns (3) and (4), however, show that after controlling for a linear or quadratic trend, the estimated impact of legalization is either small and insignificantly positive or small and insignificantly negative. ${ }^{9}$

The results therefore provide no evidence that legalization increased opium consumption. It is possible, however, that legalization caused a substitution from imported to domestic opium, at least after 1870 when China legalized domestic production. To examine this hypothesis, we examine the price of opium exported from India. If legalization caused a substantial substitution, the price of opium exports should have fallen after legalization.

Figure 2 shows the price of opium at the scales in India. The price is volatile early in the $19^{\text {th }}$ century. ${ }^{10}$ Prices appears to have increased (slightly) rather than decreased after legalization, which is the opposite of what should have occurred due to a substitution from imported to domestic opium. Table 2 examines the impact of legalization on the price of opium exports. The coefficient on legalization is negative without controls for pre-existing trends but

\footnotetext{
${ }^{8}$ Data on population are from Mitchell (1982). Data on the price of rice are from Wang (1992).

${ }^{9}$ We have also estimated these regressions for the 1831-1902 period, since the imperial prohibition opium strengthened in 1831, and for the 1840-1902 period, since the data source for exports changes in 1840. These auxiliary regressions show if anything less impact of legalization on exports.
} 
insignificantly positive with controls for pre-existing trends. There is no evidence, therefore, that legalization changed the path of export prices.

\section{Conclusions}

This paper has demonstrated that China's legalization of opium in 1858 was not associated with a perceptible increase in opium consumption. This conclusion is subject to several caveats, most importantly that it rests on data for opium exports from India to China, not on direct observation of Chinese opium consumption. Nevertheless, the export data fail to provide even a hint that prohibition had reduced consumption.

The other main caveat is that this conclusion may not apply to other prohibitions. Beyond the obvious differences in time and place, there is little evidence the Chinese government expended substantial resources attempting to enforce opium prohibition, despite its ample rhetoric. Thus, it is not surprising the prohibition had minimal impact. This episode nevertheless raises a cautionary note about the impact of weakly enforced prohibitions, and the abundant evasion and corruption spawned by China's opium prohibition are reminders of the constraints faced by any prohibition, even one with significant enforcement.

\footnotetext{
${ }^{10}$ Note, however, that the data source for the earlier years is different than for later years.
} 


\section{References}

Beeching, Jack (1975), The Chinese Opium Wars, New York: Harcourt Brace Jovanovich.

Booth, Martin (1996), Opium: A History, New York: St. Martin's Press.

Chang, Hsin-Pao (1974), Commissioner Lin and the Opium War, Cambridge: Harvard University Press.

Greenberg, Michael (1951), British Trade and the Opening of China 1800-1842, Cambridge, England: Trinity College Press.

International Anti-Opium Association (1922), The War Against Opium, Tientsin, China: Tientsin Press.

Mitchell, Brian R. (1982), International Historical Statistics: Africa and Asia, New York: New York University Press.

Newey, Whitney and Kenneth D. West (1987), "A Simple Positive Semi-Definite, Hetoroskedastic and Autocorrelation Consistent Covariance Matrix," Econometrica, 55(3), 703-708.

Office of the Superintendent of Government Printing, Calcutta India (1903), Financial and Commercial Statistics of British India, Calcutta, India.

Polachek, James M. (1992), The Inner Opium War, Cambridge: Harvard University Press.

Rowntree, Joshua (1905), The Imperial Drug Trade, London: Methuen and Co.

Waley, Arthur (1995), The Opium War Through Chinese Eyes, Stanford: Stanford University Press.

Wang, Yeh-Chien (1992), "Secular Trends of Rice Prices in the Yangzi Delta, 1638-1935" in Rawski, Thomas G. and Li, Lillian M., eds, Chinese History in Economic Perspective, Los Angeles, CA: University of California Press. 
Table 1: The Effect of Legalization on Per Capita Opium Exports from India to China

\begin{tabular}{|c|c|c|c|c|}
\hline $\begin{array}{l}\text { Independent } \\
\text { Variable }\end{array}$ & (1) & $(2)$ & (3) & (4) \\
\hline Constant & $\begin{array}{l}52.3 \\
(4.29)\end{array}$ & $\begin{array}{l}51.1 \\
(0.38)\end{array}$ & $\begin{array}{l}486.6 \\
(2.95)\end{array}$ & $\begin{array}{l}751.0 \\
(9.94)\end{array}$ \\
\hline Legalization & $\begin{array}{l}134.9 \\
(8.11)\end{array}$ & $\begin{array}{l}131.8 \\
(9.67)\end{array}$ & $\begin{array}{l}18.7 \\
(0.63)\end{array}$ & $\begin{array}{l}-18.4 \\
(1.22)\end{array}$ \\
\hline War & & $\begin{array}{l}50.7 \\
(2.90)\end{array}$ & $\begin{array}{l}51.7 \\
(3.99)\end{array}$ & $\begin{array}{l}4.09 \\
(0.59)\end{array}$ \\
\hline Price of Rice & & $\begin{array}{l}-56.0 \\
(5.23)\end{array}$ & $\begin{array}{l}-39.0 \\
(3.23)\end{array}$ & $\begin{array}{l}-10.9 \\
(2.61)\end{array}$ \\
\hline Population & & $\begin{array}{l}0.32 \\
(0.93)\end{array}$ & $\begin{array}{l}-1.02 \\
(2.24)\end{array}$ & $\begin{array}{l}-2.01 \\
(9.15)\end{array}$ \\
\hline Trend & & & $\begin{array}{l}1.77 \\
(3.59)\end{array}$ & $\begin{array}{l}6.64 \\
(12.4)\end{array}$ \\
\hline Trend Squared & & & & $\begin{array}{l}-0.04 \\
(10.2)\end{array}$ \\
\hline
\end{tabular}

Newey and West (1986) $t$-statistics in parentheses. 
Table 2: The Effect of Legalization on the Price of Opium Exports from India

\begin{tabular}{|c|c|c|c|c|}
\hline $\begin{array}{l}\text { Independent } \\
\text { Variable }\end{array}$ & (1) & (2) & (3) & (4) \\
\hline Constant & $\begin{array}{l}1480.4 \\
(10.12)\end{array}$ & $\begin{array}{l}4689.1 \\
(2.52)\end{array}$ & $\begin{array}{l}2646.2 \\
(1.19)\end{array}$ & $\begin{array}{l}2791.1 \\
(1.37)\end{array}$ \\
\hline Legalization & $\begin{array}{l}-232.8 \\
(1.56)\end{array}$ & $\begin{array}{l}-363.7 \\
(1.98)\end{array}$ & $\begin{array}{l}166.9 \\
(0.52)\end{array}$ & $\begin{array}{l}146.6 \\
(0.46)\end{array}$ \\
\hline War & & $\begin{array}{l}-278.2 \\
(2.28)\end{array}$ & $\begin{array}{l}-282.4 \\
(2.45)\end{array}$ & $\begin{array}{l}-308.5 \\
(1.96)\end{array}$ \\
\hline Price of Rice & & $\begin{array}{l}282.6 \\
(3.37)\end{array}$ & $\begin{array}{l}202.7 \\
(2.45)\end{array}$ & $\begin{array}{l}218.0 \\
(2.07)\end{array}$ \\
\hline Population & & $\begin{array}{l}-9.74 \\
(2.07)\end{array}$ & $\begin{array}{l}-3.46 \\
(0.59)\end{array}$ & $\begin{array}{l}-4.05 \\
(0.76)\end{array}$ \\
\hline Trend & & & $\begin{array}{l}-8.29 \\
(2.23)\end{array}$ & $\begin{array}{l}-5.62 \\
(0.57)\end{array}$ \\
\hline Trend Squared & & & & $\begin{array}{l}-0.02 \\
(0.28)\end{array}$ \\
\hline
\end{tabular}

Newey and West (1986) $t$-statistics in parentheses 


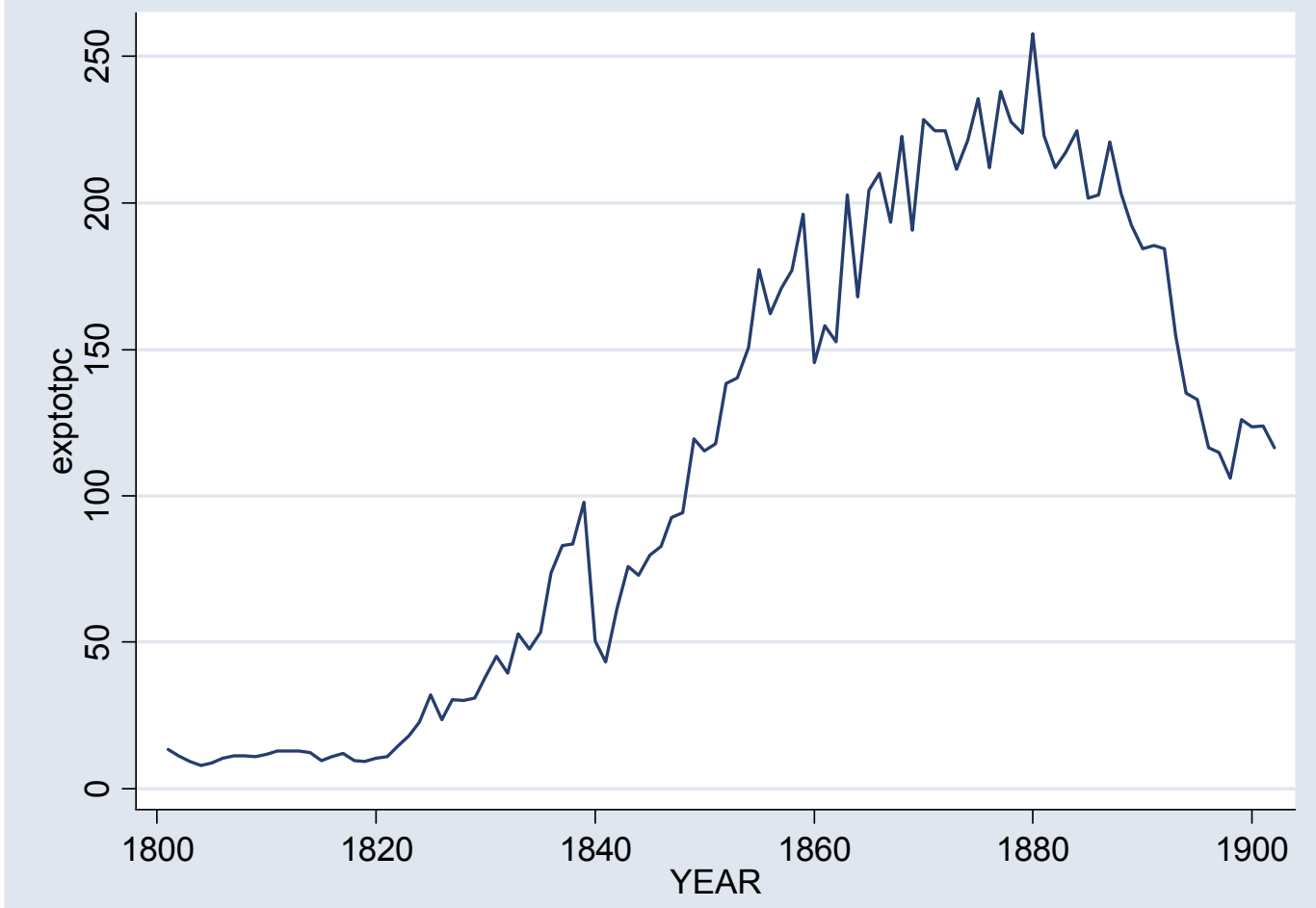

Figure 1: Opium Exports per Capita from India to China (in number of chests) 


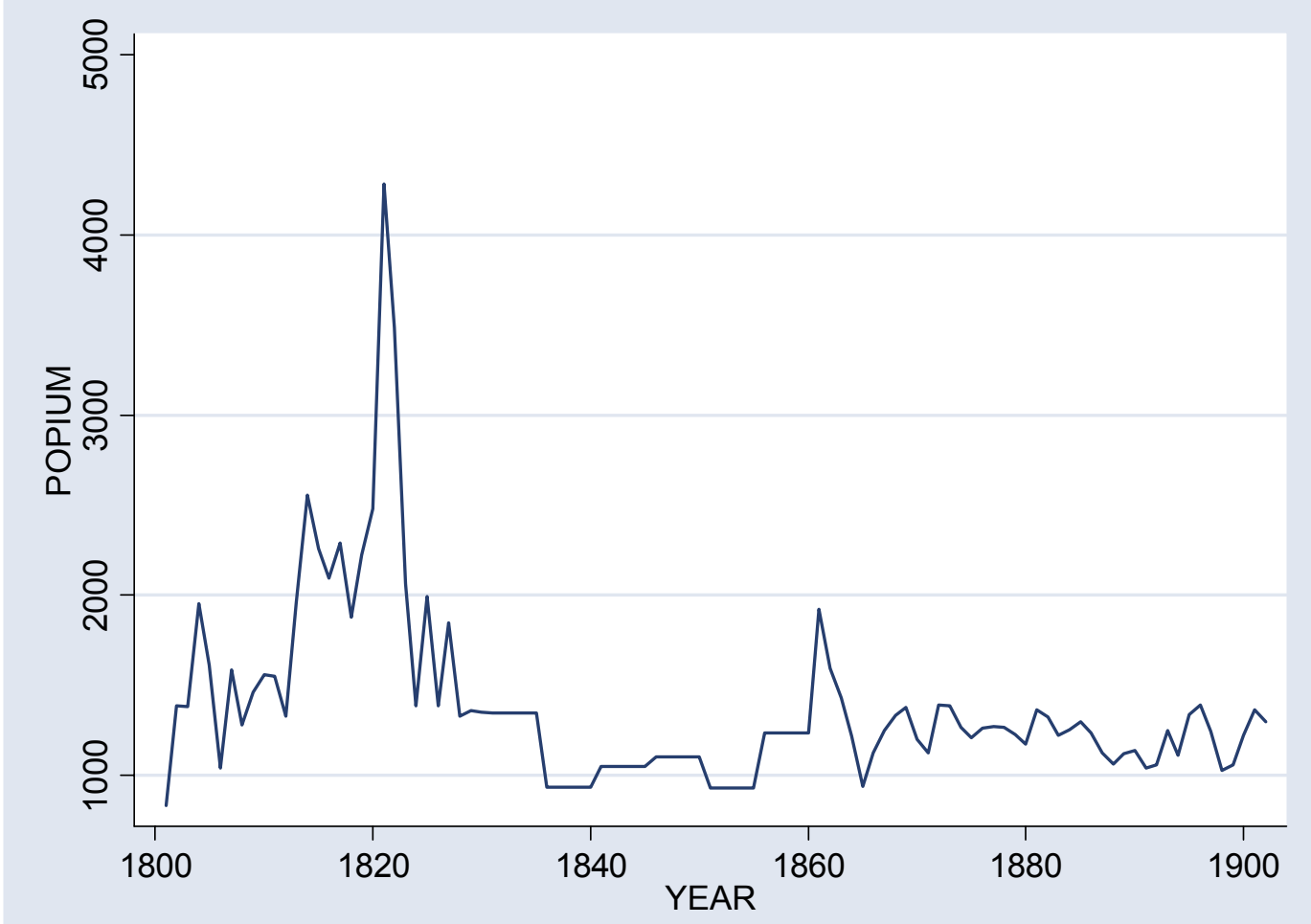

Figure 2: Price of Opium Exports in India (rupees per chest) 